\title{
UNCONDITIONAL CONSERVATISM AS A MEDIATION BETWEEN LEVERAGE AND SIZE TO FIRM VALUE
}

\author{
Dinnul Alfian Akbar'), Amri Amir ${ }^{2)}$, Sri Rahayu ${ }^{3)}$, Asep Machpuddin) \\ ${ }^{1)}$ Faculty of Economics and Islam Business, UIN Raden Fatah Palembang, Palembang Indonesia \\ ${ }^{2,3,4)}$ Faculty of Economics and Business, Universitas Jambi, Jambi Indonesia \\ Corresponding email: dinnulalfianakbar_uin@radenfatah.ac.id
}

\begin{abstract}
This research is motivated by the controversy regarding the benefits of conservative accounting numbers, intended to determine the direct effect of leverage and size on firm value, and the indirect influence of these variables through unconditional conservatism as an intervening variable on firm values in 2010 - 2017 on the Stock Exchange Indonesia. The results were that the variable unconditional conservatism can mediate the influence between size on firm value. There is a direct influence between leverage and size on firm value.
\end{abstract}

Keywords: Unconditional Conservatism, Firm Value, leverage, size

\section{Introduction}

Conservatism is a cautious reaction to the uncertainty that exists so that uncertainties and risks associated in a business situation can be adequately considered. The principle of accounting conservatism states that accountants must report the highest accounting information from several possible values of liabilities and expenses, as well as the lowest of several possible values of assets and companies (Lo, 2005). Prudence is a principle that recognizes costs and losses more quickly, recognizes income and profits more slowly, evaluates assets with the lowest value, and liabilities with the highest value. In addition, the application will produce income and asset numbers that tend to be low, cost figures that tend to be high, and the result, financial statements will produce profits that are too low (understatement).

Leverage occurs because the manager's policy in determining funding sources uses external sources, especially debt. Trade-off theory or balancing theory based on the assumption of easing Modigliani and Miller (1963). The theory states that if firm tax and bankruptcy costs are considered, the leverage relationship with firm value is non-linear. So at some point the use of debt will increase the value of the firm, namely the use of debt which provides benefits in the form of tax savings. But if at the point where the cost of bankruptcy exceeds the benefits of tax savings, then the use of debt will reduce the value of the firm.

Leverage describes the use of debt in the firm's operations. Research related to leverage has been carried out by Uchida (2006), in his research found that leverage (debt) has a positive and significant effect on firm value (Tobin's Q). In addition to the results of research by Jiraporn and Ning (2006), Faulkender et al. (2006), Amidu (2007), Li and Zhao (2007), using a measure of debt to asset ratio also shows that leverage has a positive effect on firm value. The same thing with the research conducted by Shahid (2003), Al-Malkawi (2007), Cheng and Tzeng (2011) using a debt to equity ratio.

Firm size is the size of the assets owned by the firm. Small firm will tend to use their own capital costs and short-term debt rather than long-term debt, because the costs are lower. While large companies are more likely to have strong funding sources. In this study, the measurement of firm size refers to being proxied by the value of the natural logarithm of total assets.

The size hypothesis is based on the assumption that large companies are more politically sensitive and have a greater burden of welfare transfers (political costs) than smaller companies. Large companies may have higher tax rates, but companies are also likely to gain greater political benefits (favorable agreements with government and import restrictions) as compensation for high tax rates. The larger the size of the firm, the higher the value of the firm. The increasing level of sales and total assets has an impact on increasing stock prices. With the increase in stock prices, the prosperity of shareholders will also increase. This level of sales and total assets is used as a signal for the firm to attract potential investors to invest their funds in it.

High leverage shows the amount of loan capital used to finance firm assets. The higher the results of this ratio, the greater the financial risk for creditors and shareholders. Leverage is said to be profitable if the firm can generate profits that exceed its fixed expenditure costs (constant interest on bonds and preferred stock dividends). Thus companies that have high debt will choose the application of conservative accounting. Leverage has a significant positive effect on accounting conservatism (Ahmed and Duellman, 2007). The results of Lo's (2005) study also state that the level of debt has a positive effect on the policy level of conservatism. 
Research conducted by Lo (2005) and La Fond and Roychowdhury (2007) states that leverage has a positive effect on accounting conservatism. The higher the level of leverage, the greater the likelihood of conflicts that will arise between shareholders and bondholders, which in turn will influence conservative contractual demand for accounting (Ahmed and Duellman, 2007). This is supported by research conducted by Lo (2005) and LaFond and Roychowdhury (2007) stating that leverage has a positive effect on accounting conservatism.

Lo (2005) states that firm size has a positive effect on the level of accounting conservatism, in line with the findings of Widya (2005) that firm size as a proxy for political costs has a positive influence on the selection of conservative accounting. The size hypothesis is based on the assumption that large companies are more politically sensitive and have a greater burden of welfare transfers (political costs) than smaller companies. Research conducted by Zmijewski and Hagerman (1981) supports size hypothesis, which states that large companies will choose accounting procedures that reduce reported earnings for the current period or the financial statements presented tend to be conservative. Large companies may have higher tax rates, but companies are also likely to gain greater political benefits (favorable agreements with government and import restrictions) as compensation for high tax rates. One of the things that can trigger managers to make profit declines (financial statements presented tend to be conservative) is the desire to minimize political risk (Scott, 2012).

Ahmed et.al (2002) and Zhang (2008) show that conservatism reduces the cost of debt, which makes external financing easier. $\mathrm{Li}$ (2010) found that conservatism increases cash flow from financing and increases future cash flows from operations. The various roles of conservatism such as risk reduction, availability of financing, efficiency of investment, and increase in cash provide a real channel of activity through conservatism that can prevent loss of firm value during a crisis.

LaFond and Watts (2008) prove that information asymmetry between inside and outside equity holders results in conservatism. Accounting conservatism reduces manager incentives and the ability to manipulate accounting numbers, reduce agency costs that may arise, and increase firm value and equity. Ahmed et al (2002) and Zhang (2008) show that conservatism reduces the cost of debt, which makes external financing easier. $\mathrm{Li}$ (2010) found that conservatism increases cash flow from financing and increases future cash flows from operations.

Based on the above description and previous research, the hypotheses in this study is:

$\mathbf{H}_{1}$ : Leverage affects firm value

$\mathbf{H}_{2}$ : Size affects the firm value

$\mathbf{H}_{3}$ : Mediation Conservatism has an influence between leverage and firm value

$\mathbf{H}_{4}$ : Mediation Conservatism has an influence between the size and firm value

$\mathbf{H}_{5}$ : Conservatism has an influence on firm value

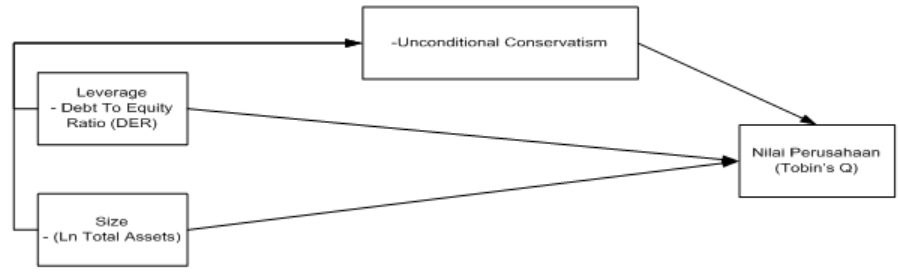

Source: developed for this study (2018)

Figure 1

Research Model

Methods

The population used in the study are companies listed on the Indonesia Stock Exchange in 2010-2017. The sample in this study were all companies listed on the Stock Exchange from 2010-2017, and had the data needed related to the measurement of the variables used for research during the period 2010-2017.

\section{Result and Discussions}

Data processing techniques using the SEM method based on Partial Least Square (PLS) require two stages to assess the Fit Model of a research model.

Table 1. R-SquareTest

\begin{tabular}{|c|c|c|}
\hline & R Square & R Square Adjusted \\
\hline Conservatism & 0,329 & 0,309 \\
\hline Nilai Perusahaan & 0,104 & 0,070 \\
\hline
\end{tabular}

Source: Output Smart PLS 3.0 M3 (2018) 
The results of the statistical output in the table above show that the adjusted R-Square value produced to explain the first model is the effect of exogenous variables (DER, Ln TA) on endogenous variables (Conservatism) of 0.309 , which means that there is an influence of exogenous variables on endogenous variables. $30.9 \%$ and the remaining $69.1 \%$ is influenced by other variables outside the second model in this study.

Furthermore, the R-SquareAdjusted value to explain the second model is the effect of exogenous variables (DER, Ln TA and Conservatism) on endogenous variables (firm Value) of 0.070 which means the influence of exogenous variables on endogenous variables is $7 \%$ and the remaining $93 \%$ is influenced by other variables excluding the second model in this study.

Table 2. Path Coefficients (Mean, STDEV, T-Values)

\begin{tabular}{|l|r|r|r|r|r|}
\hline & $\begin{array}{c}\text { Original } \\
\text { Sample (O) }\end{array}$ & $\begin{array}{c}\text { Sample } \\
\text { Mean (M) }\end{array}$ & $\begin{array}{c}\text { Standard } \\
\text { Deviation } \\
(\text { STDEV) }\end{array}$ & $\begin{array}{c}\text { T Statistics } \\
(\mid \mathbf{O} / \text { STDEV|) }\end{array}$ & \multicolumn{1}{|c|}{ P Values } \\
\hline Conservatism -> NP & $-0,318$ & $-0,317$ & 0,162 & 1,970 & 0,049 \\
\hline Lev -> Conservatism & $-0,016$ & $-0,021$ & 0,066 & 0,251 & 0,802 \\
\hline Lev -> NP & $-0,139$ & $-0,140$ & 0,035 & 3,954 & 0,000 \\
\hline Size -> Conservatism & $-0,455$ & $-0,457$ & 0,072 & 6,338 & 0,000 \\
\hline Size -> NP & $-0,282$ & $-0,289$ & 0,085 & 3,302 & 0,001 \\
\hline
\end{tabular}

Sumber: Output Smart PLS 3.0 M3 (2018)

Table 3. Total Indirect Effects

\begin{tabular}{|l|c|}
\hline & NP \\
\hline Conservatism & \\
\hline Lev & 0,005 \\
\hline NP & \\
\hline Size & 0,145 \\
\hline
\end{tabular}

Source: Output Smart PLS 3.0 M3 (2018)

\section{The Effect of Leverage on Firm Values}

$\mathrm{H}_{1}$ states that there is an influence between leverage and firm value. Based on the results of the PLS software analysis found the leverage variable has a negative and significant influence on the firm value variable. This can be seen from the coefficient value of -0.139 with a T-statistic value of 3.954 which is greater than the reference T-statistic value of 1.96. On this basis, the first hypothesis (H1) is accepted. The negative relationship of the leverage variable (DER) on the value of the firm shows that the higher the leverage (DER), the lower the value of the firm. This is because the use of debt will affect stock prices and firm value because the use of debt will cause the cost of ordinary equity to rise at the same level. With the higher debt used by companies to finance the firm's operations it will reduce firm value because with a high level of debt, the burden borne by the firm is also large. The results of this study support several research results relating to leverage variables that negatively affect the value of the firm as follows: Coles, et al (2004) provide results of leverage research has a negative and significant effect on stock price volatility or stock price volatility. The results of Coles's study, et al (2004) indicate that if leverage increases, then stock price volatility decreases which means that the firm's risk decreases. Villalonga \& Amit (2004), in his research also found that leverage has a negative and significant effect on firm value (Tobin's q).

\section{The Effect of Size on Firm Values}

$\mathrm{H}_{2}$ states there is an influence between size on firm value. Based on the results of PLS software analysis in table IV.9 found the variable size has an influence on the variable value of the firm. This can be seen from the coefficient value of -0.282 with the T-statistic value of 3.302 which is greater than the reference T-statistic value of 1.96. The results of this study indicate that it is assumed that large companies experience a tendency to attract attention and become a public spotlight, so that it will encourage the firm to implement better firm governance structures and mechanisms, thus the size of the firm has a positive effect on firm value. Firm size certainly will have a positive effect on the level of profitability achieved by the firm, as the results of research conducted by Hall and Weiss (1967). 


\section{The Effect of Unconditional Conservatism as an Mediation of Leverage on Firm Values}

$\mathrm{H}_{3}$ states that Conservatism can mediate the influence between leverage and firm value. Based on the results of PLS software analysis in the table found the conservatism variable can mediate the influence of leverage on firm value. It can be seen that leverage does not have an effect on conservatism with its T-statistic value of 0.251 which is smaller than the reference T-statistic value of 1.96. Furthermore, the conservatism variable has an influence on firm value with its T-statistic value of 1.970 which is greater than the reference Tstatistic value which is 1.96 . In addition, the PLS software and indirect effect are only 0.005 . On this basis, the hypothesis (H3) is rejected. The results of this study support Sari and Adhariani research (2009) showing that the greater the leverage ratio used to measure debt convenants, the greater the likelihood that companies will use procedures that increase reported earnings for the current period or financial statements presented tend to be not conservative (optimistic).

\section{The Effect of Unconditional Conservatism as a Mediation Between Size and Firm Value}

$\mathrm{H}_{4}$ states that Conservatism can mediate the influence between size and firm value. Based on the results of PLS software analysis in table IV.9, it is found that the conservatism variable can mediate the influence between size on firm value. It can be seen that size has an influence on conservatism with its T-statistic value of 6.338 which is greater than the reference T-statistic value of 1.96. Furthermore, the conservatism variable has an influence on the value of the firm with its T-statistic value of 1.970 which is greater than the reference T-statistic value which is 1.96. In addition, the PLS software and indirect effect are 0.145. On this basis, the hypothesis (H4) is accepted. The results of this study support the findings of Lo (2005) and Widya (2005), which states that one of the things that can trigger managers to decrease profits (financial statements presented tend to be conservative) is the desire to minimize political risk, meaning companies dealing with political costs , tend to make a profit reduction engineering with the aim of minimizing the political costs that they must bear. The results of this study are in accordance with the size hypothesis. A large size makes it easy for companies in funding problems. Companies generally have high flexibility and accessibility in funding problems through the capital market. This convenience can be captured as good information. Large size and growth can reflect the level of future profits.

\section{The Effect of Unconditional Conservatism on Firm Values}

$\mathrm{H}_{5}$ states that there is an influence between unconditional conservatism on firm value. Based on the results of PLS software analysis in table V.9, it was found that the unconditional conservatism variable had an influence on the firm value variable. This can be seen from the coefficient value of -0.318 with the T-statistic value of 1.970 which is greater than the reference T-statistic value of 1.96 . The results of this study indicate that most investors believe that the presentation of financial statements is more reliable, than they are opportunistic. The application of conservatism can be seen in PSAK (Statement of Financial Accounting Standards). The existence of PSAK in Indonesia raises the behavior of applying the principle of conservatism. Recognition of the conservatism principle in the PSAK is reflected by the existence of various choices of recording methods under the same conditions. This condition results in different figures in the financial statements which will eventually lead to conservative tendencies. The PSAK illustrates that there is an application of the principle of conservatism in Indonesia. Companies are advised to assess asset accounts on the balance sheet with a lower value, but when there is an obligation or burden management is required to immediately acknowledge the incident.

The method presented in the PSAK directly influences the figures presented in the financial statements. So that it can be said that indirectly the concept of conservatism will affect the results of the financial statements made. In addition, the application of this concept will also produce fluctuating profits which will reduce the profit predictive power to predict the firm's cash flow in the future.

This condition shows that companies in Indonesia consistently report conservative accounting figures, with the intention of giving signals to outside investors that the firm has reliable and high-quality information. This can also affect the value of the firm through its influence on financing, investment, and other real activities. These results support the research of Francis and Martin, 2010; Garcia Lara et al., 2010; Ahmed and Duellman, 2011.

\section{Conclusions}

The results of the study show that leverage affects the value of the firm, this indicates that the use of debt as a source of external funds can increase the value of the firm, as long as the present value of tax savings is greater than the cost of bankruptcy resulting from the use of debt. The firm's policy to use debt as a source of investment financing will increase the value of the firm if the use of debt is able to generate a profit greater than the interest cost of using the debt.

Size affects the value of the firm, this indicates that the greater the size of the firm, the tendency of investors to pay attention to the firm, because large companies tend to have more stable conditions and investors want to own the firm's shares, so as to increase the firm's stock price. 
The results of conservatism show that the Unconditional Conservatism has an effect on firm value, this indicates that conservatism is carried out by management on a regular basis regardless of the condition of the firm, which routinely accelerates the recognition of expenses and routinely delays income recognition. So this conservatism will not cause profit to fluctuate, because it is routinely carried out by management.

\section{References}

Ahmed, A. S dan S. Duellman. (2011). "Evidence on the role of accounting conservatism in monitoring manager's investment decisions". Accounting and Finance, 51: h.609-633.

Ahmed, A., Duellman, S., 2007. Accounting conservatism and board of director characteristics: an empirical analysis. Journal of Accounting and Economics 43, 411- 437.

Ahmed, A., Billings, B., Morton, R., \& Stanford-Harris, M. (2002). The role of accounting conservatism in mitigating bondholder-shareholder conflicts over dividend policy and in reducing debt costs. The Accounting Review, 77(4), 867-890

Ahmed, A.S., Morton, R.M. and T.F. Schaefer, (2000), "Accounting Conservatism and the Valuation of Accounting Numbers: Evidence of the Feltham-Ohlson (1996) Model,” Journal of Accounting, Auditing \& Finance, v. 15 (3), pp271-292.

Al-Malkawi, Husam-Aldin Nizar (2007), "Determinants of Corporate Dividend Policy in Jordan: An Application of the Tobit Model". Journal of Economic \& Administrative Sciences, Vol. 23, No. 2: pp. 44-70.

Almilia, Luciana Spica. (2003). Teknik Pengujian Size H ypothesis dan Debt/Equity Hypotesis yang Mempengaruhi Tingkat Konservatisme Laporan Keuangan Perusahaan dengan Teknik Analisis Multinomial Logit. Jurnal Bisnis dan Akuntansi. STIE Perbanas Surabaya.

Amidu, Mohammed (2007), "How Does Dividend Policy Affect Performance of The Firm on Ghana Stock Exchange“. Investment Management \& Financial Innovations; 4, 2; ABI/INFORM Global, pp. 103137.

Basu, S., (1997), “The Conservatism Principle and the Asymmetric Timeliness of Earnings," Journal of Accounting and Economics, v. 24 (1), pp. 3-37

Basu, Sudipta., Hwang, LeeSeok., Jan, Ching-Lih., 2005., Auditor Conservatism and Analysis Quarter Earnings Forecast., Journal of Accounting and Finance Research Vol. 13, No. 5 December 2005, pp. $211-235$

Cheng, M.C dan Tzeng, ZC, (2011), The Effect of Leverage on Firm Value and How The Firm Financial Quality Influence on This Effect, World Journal of Management Vol. 3. No. 2. September 2011 Pp. 30-53

Coles, J.L., Daniel, N.D., and Neveen, L, (2004), Department of Finance W.P. Carey School of Business Arizona State University, Department of Finance Robinson College of Business Georgia State University, Managerial Incentives and Risk-Taking.

Fala, Dwiyana A. S. (2007). Pengaruh Konservatisma Akuntansi terhadap Penilaian Ekuitas Perusahaan Dimoderasi Oleh Good Corporate Governance.Simposiun Nasional Akuntansi X Unhas Makassar

Faulkender, M., Wang, R. (2006). Corporate Financial Policy And The Value Of Cash. Journal of Finance 61, 1957-1990.

Francis, Jere R. dan Xiumin Martin. (2010). “Acquisition profitability and timely loss recognition”. Journal of Accounting and Economics, No. 49, h.161-178.

Frankel, R., Sun, Y., and Wang, R. (2008). Earnings Asymmetric Timeliness and Shareholder Distributions, Retrieved from http://ssrn.com/abstract $=1157547$.

Garcia Lara, J., B. Garcia Osma, dan F. Penalva. 2010. "Conservatism and Firm Investment Efficiency". Working paper, Universidad Carlos III de Madrid.

Ghozali, I. dan A. Chariri. (2007). Teori Akuntansi. Semarang: Badan Penerbit Universitas Diponegoro.

Givoly, D., Hayn, C., (2000). The Changing Time-Series Properties Of Earnings, Cash Flows And Accruals: Has Financial Reporting Become More Conservative?, Journal of Accounting and Economics 29: 287-320.

Givoly, D. dan Hayn, C. (2002). "Rising Conservatism: Implication for Financial Analysis.” Financial Analists Journal, 56-74.

Givoly, D., C.K. Hayn, and A. Natarajan (2004). Measuring Reporting Conservatism., The Accounting Review 82 (1): 65-106.

Hall, M., dan Weiss, L. (1967), "Firms size and profitability". The Review of Economics and Statistics. pp. 319-331.

Jiraporn, Pornsit, dan Yixi Ning (2006), "Dividend Policy, Shareholder Rights, and Corporate Governance". Journal of Applied Finance - Fall/winter 2006.

LaFond, R. (2005). The influence of ownership structure on earnings conservatism, timeliness and informativeness of stock prices: a international comparison. Working Paper, University of Wisconsin-Madison, October. 
LaFond, Ryan., and Sugata Roychowdhury., (2007), Managerian Ownership and Accounting Conservatism. http://www.ssrn.com.

Lafond, R., and R. Watts. 2008, "The Information Role of Conservative Financial Statements.” Accounting Review: Forthcoming.

Lafond, Ryan., Watts, R.L. (2006). The Information Role of Conservative Financial Statements. http://papers.ssrn.com.

Lara, Juan M. G., Beatriz G. O., and Fernando Penalva. (2009). Accounting Conservatism and Corporate Governance. Review of Accounting Studies, 14(1), pp: 161-201.

Li, X. 2010. "Accounting Conservatism and the Cost of Capital: International Analysis". Working paper, London Business School

Li, Kai and Xinlei Zhao (2007), “Asymmetric Information and Dividend Policy”. Financial Management, Vol. 37, No. 4 (Winter, 2008), pp. 673-694.

Lo, Eko Widodo. 2005. "Pengaruh Tingkat Kesulitan Keuangan Terhadap Konservatisme Akuntansi". Simposium Nasional Akuntansi VIII. Solo.

Modigliani, F., and M. Miller, (1958), The Cost of Capital, Corporation Finance, and the Theory of Investment, American Economic Review 48 (3), pg. 261-297.

Modigliani, F and Miller, M., (1963), Corporate Income Taxes and The Cost of Capital: A Correction, American Economic Review, 53, June, pg. 433-443.

Penman, S. H., and Xiao-Jun Zhang. (2002). Accounting Conservatism, The Quality of Earnings, and Stock Returns. The Accounting Review 77(2): 237-264.

Sari, Cynthia dan Desi Adhariani, (2009). Konservatisme Akuntansi dan Faktor- Faktor Yang Mempengaruhinya. Makalah SNA XII.

Scott, William R. (2012). Financial Accounting Theory. Sixth Edition. Pearson: Canada.

Scott, William., (2009). Financial Accounting Theory (5th Edition), Prentice Hall

Shahid, Shahira Abdel, (2003), "Does Ownership Structure affect firm Value? Evidence from the Egyptian Stock Market". Working Paper Series, http://ssrn.com/abstract=378580.

Tjhen, Fabian Tjandra; Saleh, M. Hasbi; dan Stinjak, Tumpal JR, (2012), Pengaruh Konservatisme Akuntansi Terhadap Nilai Perusahaan Dimoderasi Oleh Good Corporate Governance, Volume 1 No. 1 Februari 2012

Titman S and Wessels R. (1988). The determinants of capital structure choice. Journal of Finance, 43(1):1-19.

Uchida, Konari, (2006), Determinants of stock option use by Japanese companies; Review of Financial Economics, Volume 15, Issue 3, 2006, 251-269

Villalonga, B., and Amit, R, (2006), How Do Family Ownership, Management, and Control Affect Firm Value?. Journal of Financial Economics, Volume 80, Issue 2, May 2006, Pages 385-417

Wardhani, Ratna. (2008). Tingkat Konservatisme Akuntansi di Indonesia dan Hubungannya dengan Karakteristik Dewan Sebagai Salah Satu Mekanisme Corporate Governance. Makalah SNA XI, Pontianak

Wardhani, Ratna, (2009),. Pengaruh Proteksi Bagi Investor, Konvergensi Standar Akuntansi, Implementasi Corporate Governance, Dan Kualitas Audit Terhadap Kualitas Laba: Analisis Lintas Negara Di Asia, Disertasi, Universitas Indonesia, Depok

Widya. (2005). Analisis Faktor-Faktor yang Mempengaruhi Pilihan Perusahaan terhadap Akuntansi Konservatif. Simposium Nasional Akuntansi VII, Bali.

Zhang, J., (2008). The Contracting Benefits Of Accounting Conservatism To Lenders And Borrowers. Journal of Accounting and Economics 45, 27-54.

Zimmerman, J., L. (1983). Taxes and Firm Size. Journal of Accounting and Economics 5. August (p. 119-149).

Zmijewski, M., dan R. Hagerman. (1981). An Income Strategy Approach to the Positive Theory of Accounting Standard Setting/Choice. Journal of Accounting and Economics 3. August (p. $129-$ 149).

\section{Authors' Bibliography}

Dinnul Alfian Akbar, was born in Palembang, Sumatera Selatan, March $27^{\text {th }}, 1978$. He graduated the bachelor degree from Economic Faculty of Muhammadiyah University in 1999, and master degree from Master of Science of Gadjah Mada University in 2002.

Currently, Dinnul Alfian Akbar on progress to accomplish the doctoral program of Finance Management from Economic Faculty of Jambi University in Jambi. 